Article

\title{
Climate Change Induced Salinization of Drinking Water Inlets along a Tidal Branch of the Rhine River: Impact Assessment and an Adaptive Strategy for Water Resources Management
}

\author{
Matthijs van den Brink ${ }^{1, *}$, Ymkje Huismans ${ }^{2}$, Meinte Blaas ${ }^{3}$ and Gertjan Zwolsman ${ }^{4}$ \\ 1 HydroLogic, P.O. Box 2177, 3800 CD Amersfoort, The Netherlands \\ 2 Deltares (Unit Marine and Coastal Systems), P.O. Box 177, 2600 MH Delft, The Netherlands; \\ ymkje.huismans@deltares.nl \\ 3 Rijkswaterstaat (Unit of Water, Traffic \& Environment, Dept. of Water Management), Ministry of \\ Infrastucture \& Water Management, P.O. Box 2232, 3500 GE Utrecht, The Netherlands; meinte.blaas@rws.nl \\ 4 Dunea, Plein van de Verenigde Naties 11, 2719 EG Zoetermeer, The Netherlands; g.zwolsman@dunea.nl \\ * Correspondence: matthijs.vandenbrink@hydrologic.com; Tel.: +31-6-50636712
}

Received: 28 February 2019; Accepted: 26 March 2019; Published: 2 April 2019

check for updates

\begin{abstract}
This study presents the results of an impact analysis of climate change on salinization and the long-term availability of drinking water resources along the river Lek, a tidal branch of the Rhine delta, and a potential mitigation measure. To this end, a one-dimensional modelling approach was used that enabled studying 50 years of variation in discharge and tide in current and future climate. It was found that all locations are increasingly vulnerable to salt intrusion caused by the combination of sea level rise and decreasing river discharges. This affects both the yearly average chloride concentration and long duration exceedances of the threshold value of $150 \mathrm{mg} / \mathrm{L}$. It was also found that diverting a higher fresh water discharge to the Lek of several tens of cubic meters per second reduces the risk of salinization at the upstream inlet locations. However, the increased influence of seawater intrusion on the drinking water inlets cannot be fully compensated for by this measure. The potential gain of the extra water for the drinking water inlets along the Lek has to be balanced against the impact of this measure on water levels and stream flows in other parts of the river system.
\end{abstract}

Keywords: climate change; salinization; water resources management; drinking water

\section{Introduction}

The Netherlands constitute a densely populated part of the Rhine-Meuse delta. Due to an annual precipitation surplus of $300 \mathrm{~mm}$ and border crossing discharges of the Rhine and Meuse rivers (averaging at $2200 \mathrm{~m}^{3} / \mathrm{s}$ and $230 \mathrm{~m}^{3} / \mathrm{s}$ respectively), fresh water supply has not been an issue before long. However, the country's limited elevation and the proximity of the sea make The Netherlands vulnerable to seawater intrusion and salinization of freshwater inlets.

Seawater intrusion in river deltas is largely governed by two variables, both subject to climate change:

- Sea level rise. Climate projections for The Netherlands show an estimated sea level rise of 0.15 to $0.40 \mathrm{~m}$ in the year 2050, and an increase of 0.25 to $0.80 \mathrm{~m}$ by 2085, compared to the reference year 1985 [1]. 
- A lower river baseflow. The regionalized climate projections indicate a potential worst case decrease of 20 percent of the annual 7-day minimum discharge for the Rhine in 2050 and a 30 percent decrease in 2085, compared to the reference year 1985 [2].

Both drivers cause the sea water to penetrate further inland, through the open river-sea connection in the estuary.

Several impact assessments [3,4] show that in the long term, fresh water supply in The Netherlands is at risk, especially in the low-lying western area where salt water intrusion occurs, whereas the dependence on surface water is highest, due to the presence of brackish ground water. As part of the national Delta Programme [5], national and regional governments, water authorities and public and private water users jointly seek opportunities to make fresh water supply resilient to climate change. This study presents the results of an impact analysis of climate change on the long-term availability of drinking water resources in the river Lek, a tidal branch of the Rhine delta. In addition, we will explore a potential measure to protect these freshwater resources by reallocating the Rhine discharge over its various branches in the delta.

The Lek serves as a drinking water source to approx. 2.2 million inhabitants in the southwest The Netherlands. There are six indirect abstractions present along the river (river bank filtration) and one direct surface water intake. The water treatment does not include desalination, as the chloride concentration of the river water hardly ever exceeds the drinking water standard of $150 \mathrm{mg} / \mathrm{L}$. However, given the impacts of climate change on river flow and sea level rise, it is conceivable that some of the freshwater intakes along the Lek are vulnerable to salinization.

The research questions of the analysis are:

1. To what extent may climate change increase the probability of salt intrusion on the Lek, limiting its quality as drinking water source?

2. To what extent can salt water intrusion be reduced by diverting a higher fresh water discharge towards the Lek?

These research questions are addressed by this study using a mathematical modelling approach, integrating river flow, seawater level and salt loads of the system. As salt intrusion on the Lek has not been studied in such detail before, an existing salt transport model of the estuary was updated in order to assess the vulnerability of the freshwater inlets along the Lek towards salinization due to climate change. Additionally, the model was used to assess the effectiveness of diverting higher freshwater discharges to the Lek, in order to alleviate future salinization events. The effectiveness of the diversion strategy is evaluated in terms of our understanding of when and where different salinization mechanisms prevail.

\section{System Description, Methods and Materials}

\subsection{Northern Rhine Delta Basin (NDB) System Description}

The Rhine river splits into several branches just upstream of the city of Arnhem (Figure 1). The distribution of the discharge over the branches can be controlled to a limited extent by a weir near the city of Arnhem. On average, two thirds of the river flow is directed to the Waal branch, while the Lek receives some $10-15 \%$ of the cross border flow of the Rhine. The allocation of the river flow along the Lek river can be controlled by three weirs (see Figure 1). 


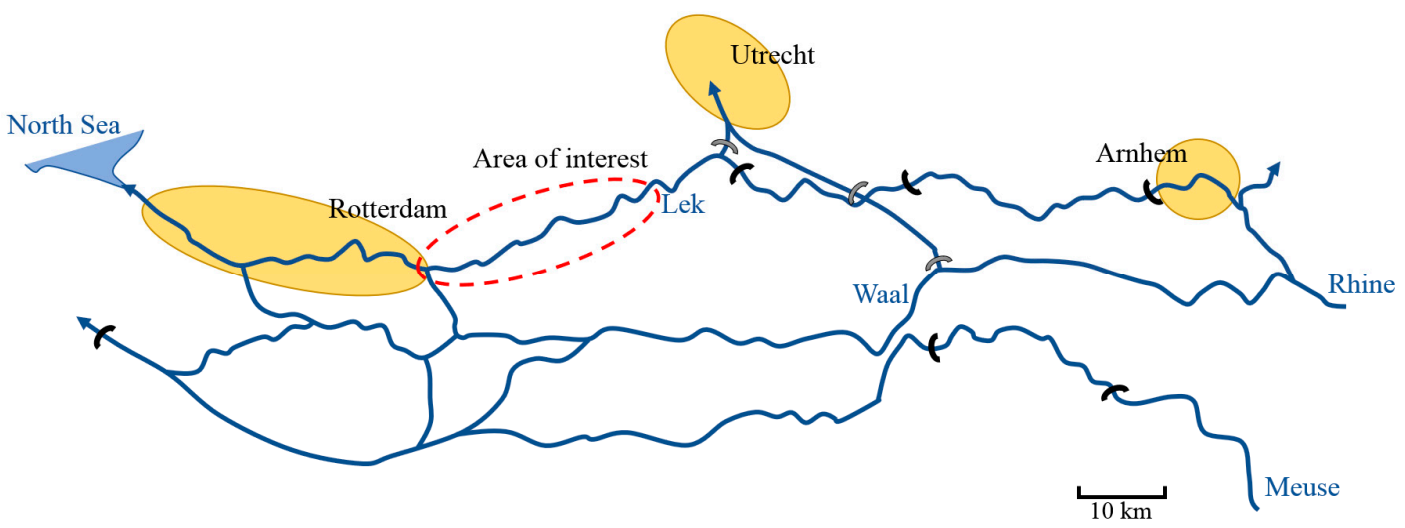

Figure 1. The Rhine-Meuse delta and the location of the area of interest. River flow on the Lek can be controlled by the three weirs in the river. Major cities are depicted by the yellow ovals.

The Rhine-Meuse delta is situated in the western part of the country. Here, the Rhine branches connect with the Meuse river, before flowing into the North Sea through two major outlets. The southern outlet is controlled by sluices (Haringvliet), and the northern outlet is an open shipping channel (Rotterdam Waterway). Sea water enters the estuary through this northern channel.

The western part of the Lek (area of interest; see Figure 1) is a tidal branch of the river Rhine with an open connection to the sea. The discharge is controlled by a weir (Hagestein). During periods of low discharge on the Rhine (below $1500 \mathrm{~m}^{3} / \mathrm{s}$ ), the Lek receives a minimal net discharge of $1-10 \mathrm{~m}^{3} / \mathrm{s}$. The drinking water inlets under study are situated at two different locations along the downstream section of the Lek, Kinderdijk and Bergambacht (Figure 2, Table 1). Close to Streefkerk, a third location is planned in the near future. At all locations, the type of inlet is river bank filtration: the water is extracted at 40-50 m below surface [6]. Additionally, at Bergambacht, there is an open water intake.

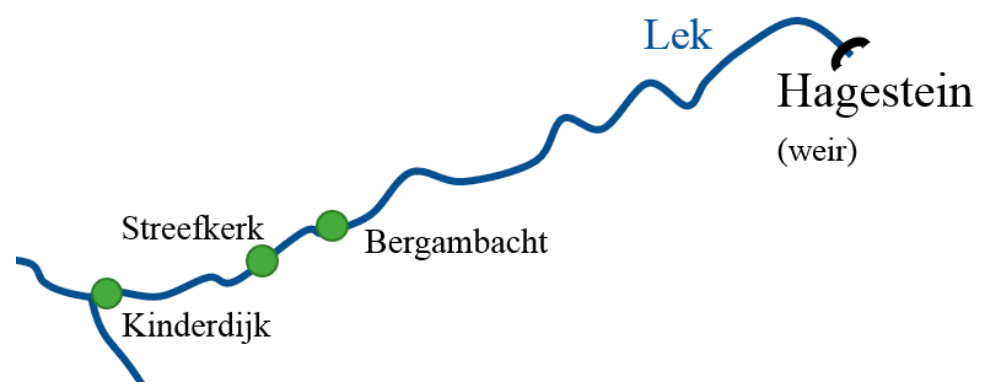

Figure 2. Location of the drinking water inlets along the Lek river.

Table 1. Location and annual extraction volumes of drinking water inlets along the Lek river.

\begin{tabular}{cccc}
\hline Inlet & $\begin{array}{c}\text { Distance to Mouth } \\
\text { of Lek }\end{array}$ & Type of Inlet & $\begin{array}{c}\text { Average Annual } \\
\text { Extraction }\end{array}$ \\
\hline Bergambacht & $12 \mathrm{~km}$ & $\begin{array}{c}\text { (a) Direct } \\
\text { (b) River bank filtration }\end{array}$ & $\begin{array}{c}\text { (a) } 92 \mathrm{Mm}^{3} \\
\text { (b) } 13 \mathrm{Mm}^{3}\end{array}$ \\
\hline Streefkerk (planned) & $8 \mathrm{~km}$ & River bank filtration & $4-6 \mathrm{Mm}^{3}$ \\
\hline Kinderdijk & $0.5 \mathrm{~km}$ & River bank filtration & $6 \mathrm{Mm}^{3}$ \\
\hline
\end{tabular}

The mouth of the Lek, just downstream from the intake at Kinderdijk, is situated approximately $42 \mathrm{~km}$ from the North Sea. Salt intrusion in the mouth of the Lek commonly occurs during low river flows and high seawater levels. However, it is expected that salinization of the Lek rapidly decays in upstream direction, although few measurement data exist to date to support this view. A typical example of salinization of the mouth of the Lek is presented in Figure 3, showing the situation in the second half of 2018 when a severe hydrological drought occurred in the Rhine river catchment. 

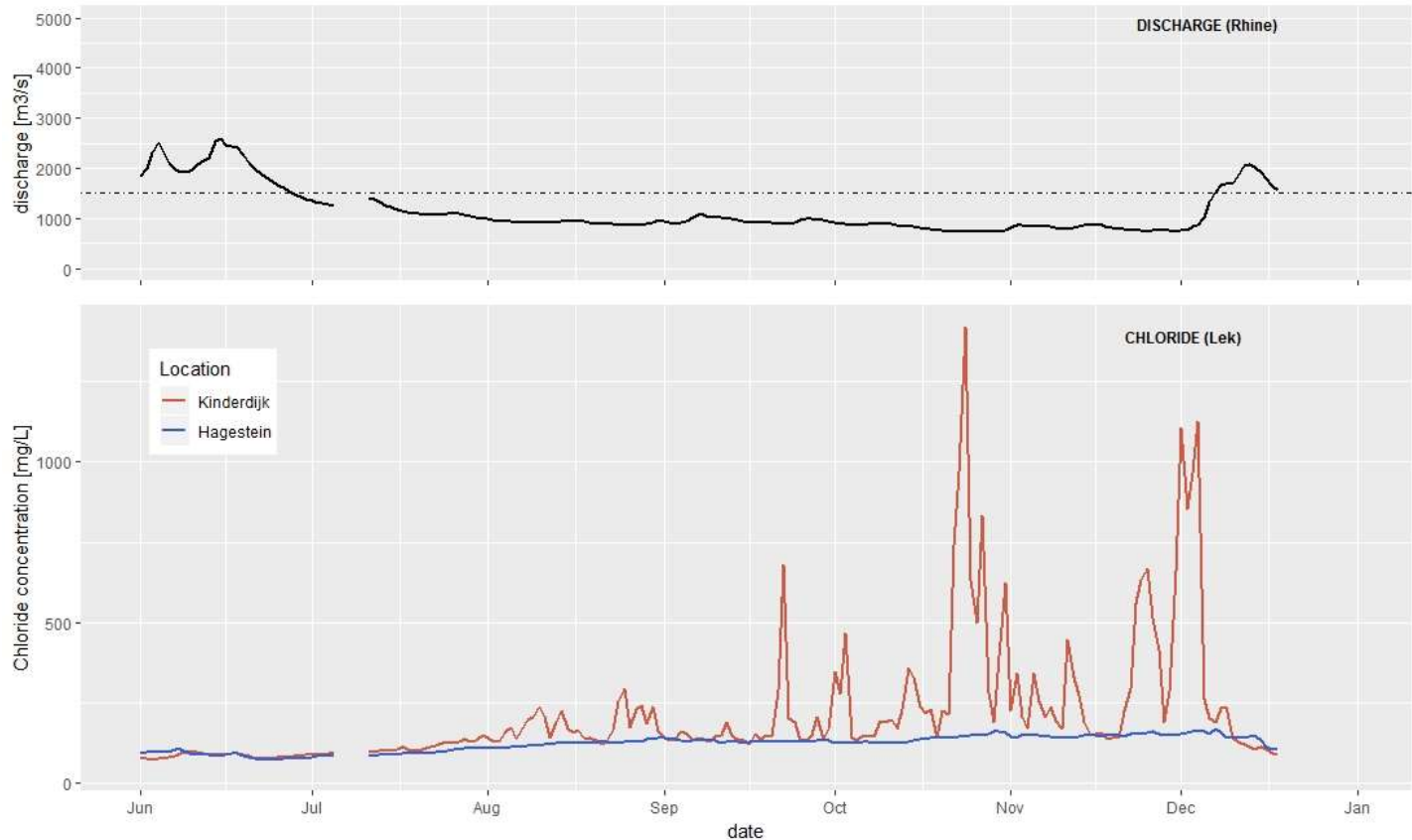

Figure 3. Flow of the Rhine River and salinization of the mouth of the Lek during a hydrological drought in the second half of 2018. Averaged on daily basis but based on 10 min measurements.

Calculations show [7] that the tidal excursion-the distance a water particle travels during a tidal cycle [8] - at the Lek is 6 to $7 \mathrm{~km}$ from the mouth under average tidal conditions. This distance increases during spring tide and can reach up to $14 \mathrm{~km}$ during storm surges. This implies that the inlet at Kinderdijk is situated within reach of the average tidal excursion. The intake locations at Streefkerk and Bergambacht which are situated more upstream (Figure 2) will only face salinization during storm surges or through mixing processes causing longitudinal dispersion.

The sea is not the only source of salt in the Lek. On the freshwater side, the Rhine carries a salt load as well. The chloride concentration of the Rhine river can be described by the relationship $C(t)=C_{b}+L_{c} / Q(t)$, where $C_{b}$ is the background chloride concentration and $L_{c}$ is the chloride load. In [9], estimates for $C_{c}$ and $L_{c}$ were derived from measurements in 2007-2008 $\left(L_{c}=60 \mathrm{~kg} / \mathrm{s}\right.$; $\mathrm{C}_{\mathrm{b}}=47 \mathrm{mg} / \mathrm{L}$ ). Using these estimates, the typical chloride concentration for low discharges $\left(800-1500 \mathrm{~m}^{3} / \mathrm{s}\right)$ ranges from 90 to $125 \mathrm{mg} / \mathrm{L}$. A more recent estimate of this riverine chloride concentration (i.e., the combination of background chloride concentration and chloride load), based on the year 2011, results in a range of $97-141 \mathrm{mg} / \mathrm{L}$.

\subsection{NDB-Model}

For assessing the impact of climate change on salinization of the Lek and the effectiveness of mitigation measures, preferably long time series are calculated in which a large set of variations in conditions like river discharge, tide and wind conditions occur. To date, this can only be carried out with 1D models, which are a commonly applied for hydrodynamic calculations in river studies [10]. Therefore, a 1D hydrodynamic model of the Rhine-Meuse estuary was used to describe the transport of water and salt. This Northern Delta Basin (NDB) model is part of the Dutch National Water Model (NWM), a set of hydraulic and hydrological models and tools set up to support the national fresh water policy [11]. With the NWM model, the hydrology and water distribution throughout The Netherlands can be calculated [12-14]. From this, boundary conditions are extracted for the nested and more detailed NDB model [13-15].

The NDB model is setup in the SOBEK-RE modelling suite, a one-dimensional open-channel dynamic numerical modelling system [16]. Salt transport in the NDB is modelled by a 1D longitudinal advection-dispersion formulation. The advective part describes the distribution of salt along with 
the 1D motion of the water. Other processes contributing to the distribution of salt that, due to limited dimensions and spatial scale, cannot be resolved by the model are described by the dispersion coefficient. This covers 3D mixing processes like gravitation, circulation and Taylor shear dispersion. Within SOBEK-RE, the dispersion coefficient is estimated by the adjusted version of the Thatcher-Harleman equation [17-19].

The current version of the NDB model (NDB1_1_0) was setup in 2003 [20] and recalibrated in 2005 [21]. Due to its relative long distance from the mouth of the estuary, the river Lek has as yet not been vulnerable to salinization, except for its mouth at Kinderdijk. As a consequence, little data is available and calibration of the NDB model has never focused on the Lek. Only recently, a range for the longitudinal dispersion coefficients was estimated for this part of the Rhine estuary [7], based on an analytic expression for salt dispersion in combination with system knowledge and branch characteristics. An overview of the obtained values is given in Table 2. It shows that the estimate for the dispersion coefficient varies with conditions, like discharge, salinity gradient and location within the estuary. However, the adjusted Thatcher-Harleman formulation in the NDB model is not able to capture this behavior. Therefore, in this study a range of fixed values was used, depending on the minimum upstream discharge at Hagestein (the most right column in Table 2).

Table 2. Overview of the values for the dispersion coefficient $\mathrm{K}$ for Kinderdijk and Bergambacht as presented in [7]. All numbers rounded to fives. $\Delta \mathrm{C}$ is the increase in chloride concentration with respect to the riverine concentration. $K_{\min }$ and $K_{\max }$ are the minimum and maximum estimate for the dispersion coefficient. Estimates for $40 \mathrm{~m}^{3} / \mathrm{s}$ were calculated following the same method as in [7].

\begin{tabular}{|c|c|c|c|c|c|c|}
\hline \multirow{2}{*}{$\begin{array}{c}\text { Discharge } \\
\mathrm{m}^{3} / \mathrm{s}\end{array}$} & \multirow[t]{2}{*}{ Location } & \multicolumn{2}{|c|}{$\Delta \mathrm{C}=50 \mathrm{mg} \mathrm{Cl} / \mathrm{L}$} & \multicolumn{2}{|c|}{$\Delta \mathrm{C}=500 \mathrm{mg} \mathrm{Cl} / \mathrm{L}$} & \multirow[t]{2}{*}{ Value Used } \\
\hline & & $K_{\min }$ & $K_{\max }$ & $K_{\text {min }}$ & $K_{\max }$ & \\
\hline \multirow[t]{2}{*}{2} & Kinderdijk & 25 & 65 & 30 & 80 & \multirow{2}{*}{55} \\
\hline & Bergambacht & 25 & 65 & 30 & 80 & \\
\hline \multirow[t]{2}{*}{20} & Kinderdijk & 30 & 80 & 55 & 125 & \multirow{2}{*}{90} \\
\hline & Bergambacht & 25 & 65 & 25 & 70 & \\
\hline \multirow[t]{2}{*}{40} & Kinderdijk & 35 & 90 & 70 & 150 & \multirow{2}{*}{110} \\
\hline & Bergambacht & 25 & 65 & 25 & 70 & \\
\hline
\end{tabular}

The minimum value used in this study is the average of the estimates for a discharge of $2 \mathrm{~m}^{3} / \mathrm{s}$, i.e., $55 \mathrm{~m}^{2} / \mathrm{s}$. For higher upstream discharges, the dispersion coefficient shows a variation with location along the Lek. The aim of this study is to assess the impact of increasing the upstream discharge on this river branch. To prevent overestimation of the effect of the measure, the dispersion values used were based on the average estimates for the most downstream location (Kinderdijk) and the highest gradient in chloride concentration $(\Delta \mathrm{C}=500 \mathrm{mg} \mathrm{Cl} / \mathrm{L})$.

To assess the impact of this approach, sensitivity calculations have been carried out for an 8-year period. For the reference case, the range of $D=25-80 \mathrm{~m}^{2} / \mathrm{s}$ has been explored, which coincides with the full range estimated in Table 2. For the case with a minimum discharge of $20 \mathrm{~m}^{3} / \mathrm{s}$, the range has been extended from $90 \mathrm{~m}^{2} / \mathrm{s}$ towards the lowest value estimated in Table $2\left(D=25 \mathrm{~m}^{2} / \mathrm{s}\right)$, since $D=90 \mathrm{~m}^{2} / \mathrm{s}$ is expected to be a conservative estimate for the dispersion coefficient, based on typical hydrodynamic and salinity gradient conditions at Kinderdijk. In practice, the dispersion coefficient further upstream of Kinderdijk will be lower.

The results of this sensitivity analysis are shown in Figure 4, in which the 365-day moving average of chloride at Streefkerk is given for the minimum and the $20 \mathrm{~m}^{3} / \mathrm{s}$ discharge cases. It shows that the range of the dispersion coefficient is relevant to the results, but that the effect of the upstream discharge is larger, provided the difference in upstream discharge is sufficiently large (some tens of cubic meter per seconds). 


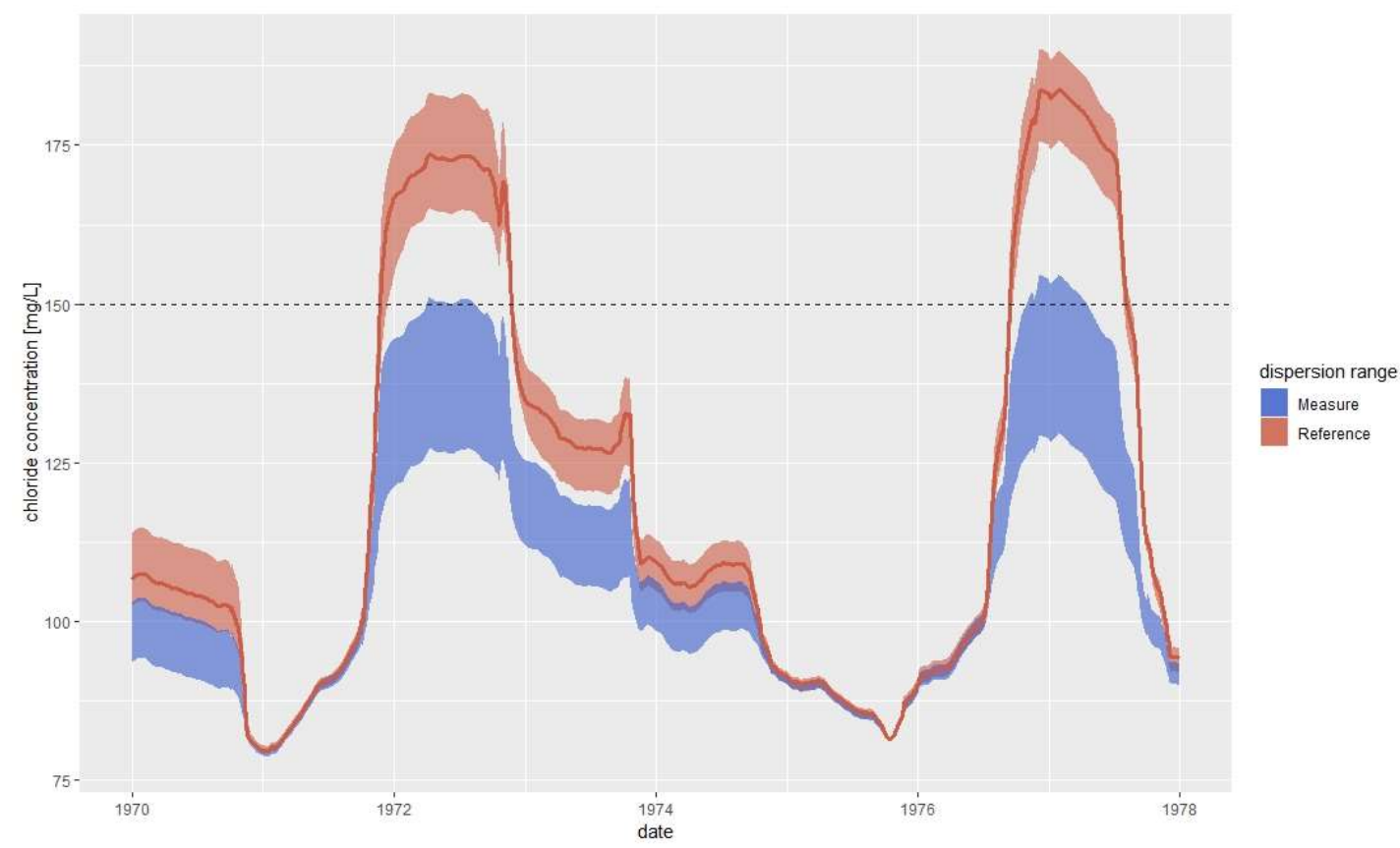

Figure 4. The sensitivity of the 365-day moving average chloride concentration at Streefkerk for the range of the dispersion coefficient: $Q_{u p, \min }=2 \mathrm{~m}^{3} / \mathrm{s}$ (reference): $D=25-80 \mathrm{~m}^{2} / \mathrm{s}$ (orange); $\mathrm{Q}_{\text {up } \min }=20 \mathrm{~m}^{3} / \mathrm{s}: D=25-90 \mathrm{~m}^{2} / \mathrm{s}$ (blue).

The model setup was validated against observed chloride concentrations at Kinderdijk, available for the period 2001-2011 (no observations were available for the other two locations). Figure 5 illustrates the behavior of the model; it describes the overall variations reasonably well. The model is able to reproduce sudden salinization events due to sea water intrusion. However, the magnitude of the peaks is underestimated.

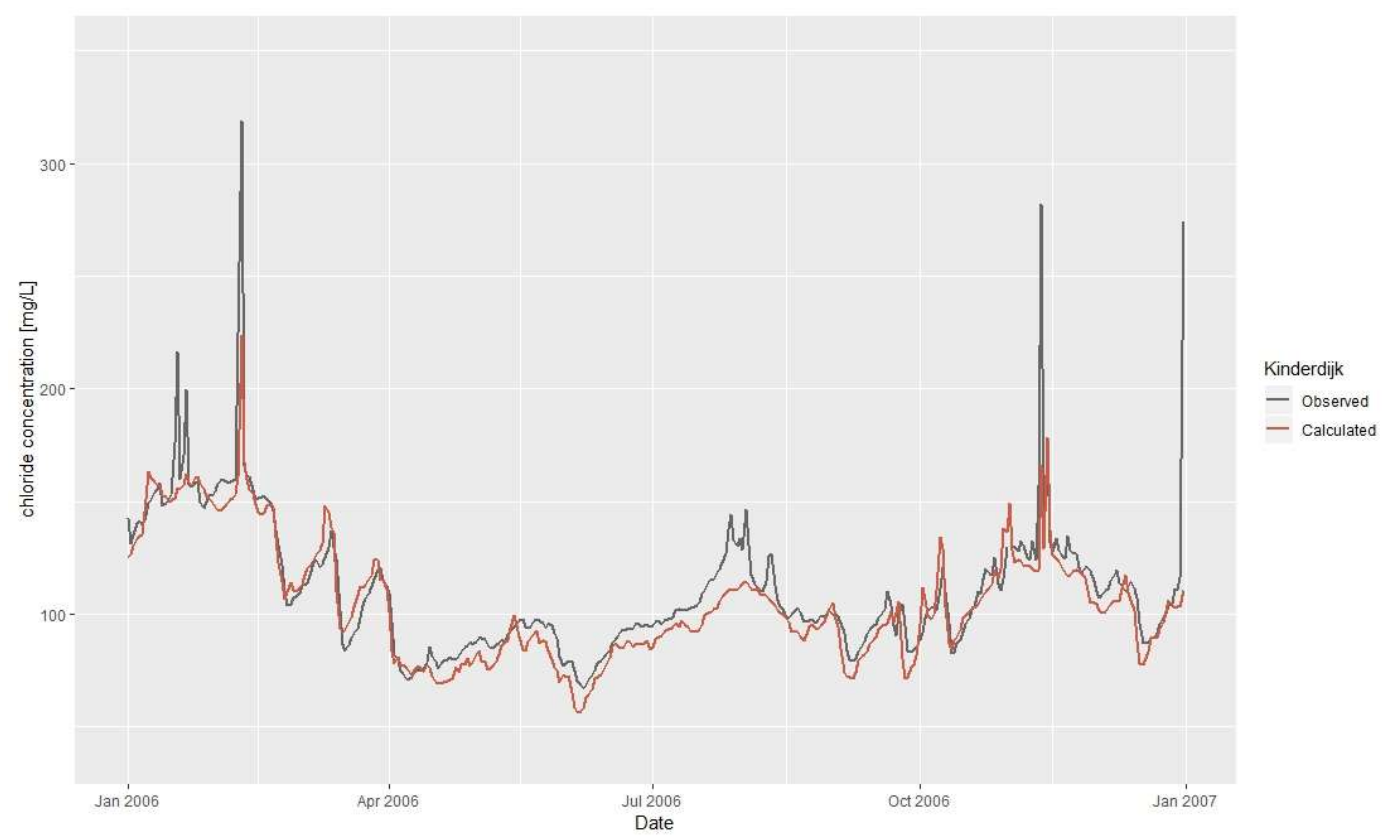

Figure 5. Observed and calculated chloride concentrations at Kinderdijk for the year 2006. Both observations and calculations are daily averaged based on $10 \mathrm{~min}$ data. Please note that for the validation runs, measured river chloride concentrations are used, while for the scenario runs (current and future climate), a discharge-salinity relation is used. 
This general model performance can also be observed from Figure 6, where the 365-day moving average is plotted for the observed and modelled chloride concentrations at Kinderdijk. The averaged chloride concentration is underestimated for years with a substantial impact of seawater intrusion, like the year 2003 .

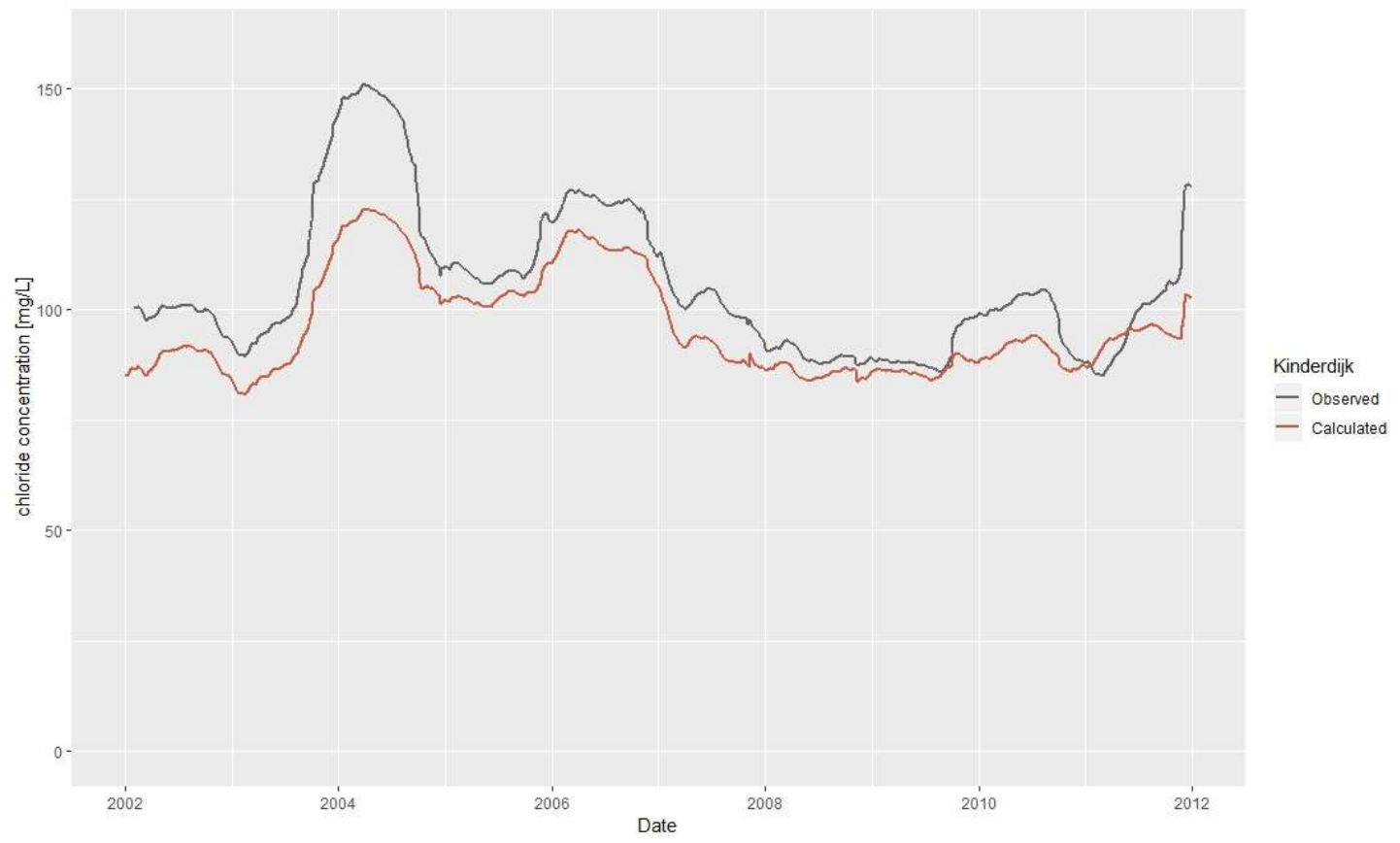

Figure 6. Comparison of the observed and modelled 365-day moving average chloride concentration at Kinderdijk. Please note that the moving average is tailing, that is, the salinization events occurring in the summer and autumn of 2003 start to have a noticeable effect on the MA in the second half of 2003 and remain visible until the second half of 2004.

From this validation, and in line with previous findings [22], it can be concluded that the model is well able to capture salinization events, but that exact variations differ and the influence of sea water intrusion is underestimated. As variations in chloride concentration in the Lek vary between about $50 \mathrm{mg} \mathrm{Cl} / \mathrm{L}$ up to over $3500 \mathrm{mg} \mathrm{Cl} / \mathrm{L}$, estimating exact exceedance durations of a threshold of $150 \mathrm{mg} \mathrm{Cl} / \mathrm{L}$ requires a very high accuracy of the model. The validation shows that this accuracy cannot be achieved with this basin wide 1D model. In addition, the limited representation of the physical processes relevant for salinity intrusion in 1D poses an uncertainty on the predictability with changing conditions such as sea level rise. However, a global indication on the amount and duration of exceedance in current and future climate can be obtained. The model can therefore be used to carry out a first-order assessment of the vulnerability of the inlet locations to salinization and of the risk reduction that can be achieved by reallocating the available water over the Rhine branches. However, it should not be used in an operational water management context, where more precise estimates are required for a day to day balancing of the freshwater allocation to the Lek and the salinization potential of the intake locations.

\subsection{Climate Projection}

The climate projection used in this study is the Wh-dry scenario for the Rhine river catchment [1,2]. This scenario is part of the KNMI'14 climate scenarios [23] — a regionalized interpretation of the AR5 climate projections-and serves as the worst case scenario from a fresh water supply perspective. The Wh-dry scenario projects a change in meteorological conditions (precipitation and evapotranspiration) in The Netherlands, impacting the intake and outlet discharges from the river Lek. Furthermore, the Wh-dry scenario projects for 2050 a sea level rise of $40 \mathrm{~cm}$ relative to 1995 . The Wh-dry scenario projects 
a strong reduction in summer precipitation in the Rhine catchment by $17 \%$ in 2050 [1] and leads to a longer duration and severity of low Rhine river discharges entering The Netherlands. For example, the long term mean annual lowest seven-day flow drops from $1010 \mathrm{~m}^{3} / \mathrm{s}$ in current conditions to $825 \mathrm{~m}^{3} / \mathrm{s}$ in 2050 in Wh-dry conditions, and the number of days with a flow below $1000 \mathrm{~m}^{3} / \mathrm{s}$ doubles from 23 to 46 [2].

To assess the potential impact of climate change under the Wh-dry scenario on salt water intrusion, the NDB model was rerun with adjusted boundary conditions according to the Wh-dry scenario. The 50-year time series of future river discharges and lateral discharges and intakes has been taken from the National Water Model as used in the context of the Delta Program fresh water supply. The projected sea level rise of $40 \mathrm{~cm}$ by 2050 has been added to the marine boundary condition of the model thereby copying the variability of tides and storm surges as historically occurred over the 1961-2011 period.

\section{Results}

\subsection{Vulnerability of Drinking Water Inlets}

The vulnerability of the drinking water inlets to salt intrusion is indicated by exceedance of the maximum allowable chloride concentration in drinking water in The Netherlands $(150 \mathrm{mg} / \mathrm{L})$. For direct inlets, no water is extracted when the concentration of $150 \mathrm{mg} \mathrm{Cl} / \mathrm{L}$ is exceeded. For the sub-surface inlets (river bank filtration), this maximum allowable concentration is a yearly average. In this section, the vulnerability of the drinking water inlets is analysed in three steps. Firstly, an indication of the increase in salinization on the Lek due to climate change is obtained by analyzing the percentage of time in which the limit of $150 \mathrm{mg} \mathrm{Cl} / \mathrm{L}$ is exceeded for all three locations along the Lek, for current and future climate. Next, the impact on the 365-day moving average is presented. Finally, the duration of the exceedances is analysed for the direct inlet at Bergambacht.

Figure 7 summarises the number of days that the chloride concentration exceeds the threshold during one or more timesteps in the 50 -year period. This exceedance can be caused by either the chloride concentration of the river water (i.e., $>150 \mathrm{mg} / \mathrm{L}$ ) or by seawater intrusion. From these occurrences, the number of days during which the riverine chloride concentration exceeds the threshold are separated. Finally, the occurrences are divided by the total number days in the 50-year period, yielding a percentage of time.

This analysis shows that for reference conditions, the percentage of time at which the threshold chloride concentration is exceeded in the 50-year period considered is close to 2 percent near the mouth (Kinderdijk) and decreases by a factor of $4-5$ at the inlet locations upstream. Exceedances of the $150 \mathrm{mg} / \mathrm{L}$ threshold due to high chloride concentrations in the river water do not occur. In a future dry climate (Wh-dry conditions), exceedance percentages increase up to 6 to 10 percent, depending on the location. Part of this increase is caused by the riverine chloride concentration, which increases during the low river discharges in the Wh-dry scenario. Please note that this effect alone already causes a $2 \%$ exceedance of the threshold at all inlet locations. This is larger than the total exceedance, from marine and river origin, in current climate conditions.

Figure 8 shows the 365 -day moving average of the chloride concentration at the three drinking water inlet locations. Under current climate conditions, the moving average does not exceed the threshold of $150 \mathrm{mg} / \mathrm{L}$ at any location during the 50 years calculation period. In the Wh-dry scenario, the increase in riverine chloride concentration during low discharges has an effect on the 365-day moving average, but does not lead to exceedances. However, in combination with the increased seawater intrusion, several periods of exceedance at all intake locations occur. In accordance with Figure 7 , the number and the duration of exceedances decrease in upstream direction. 


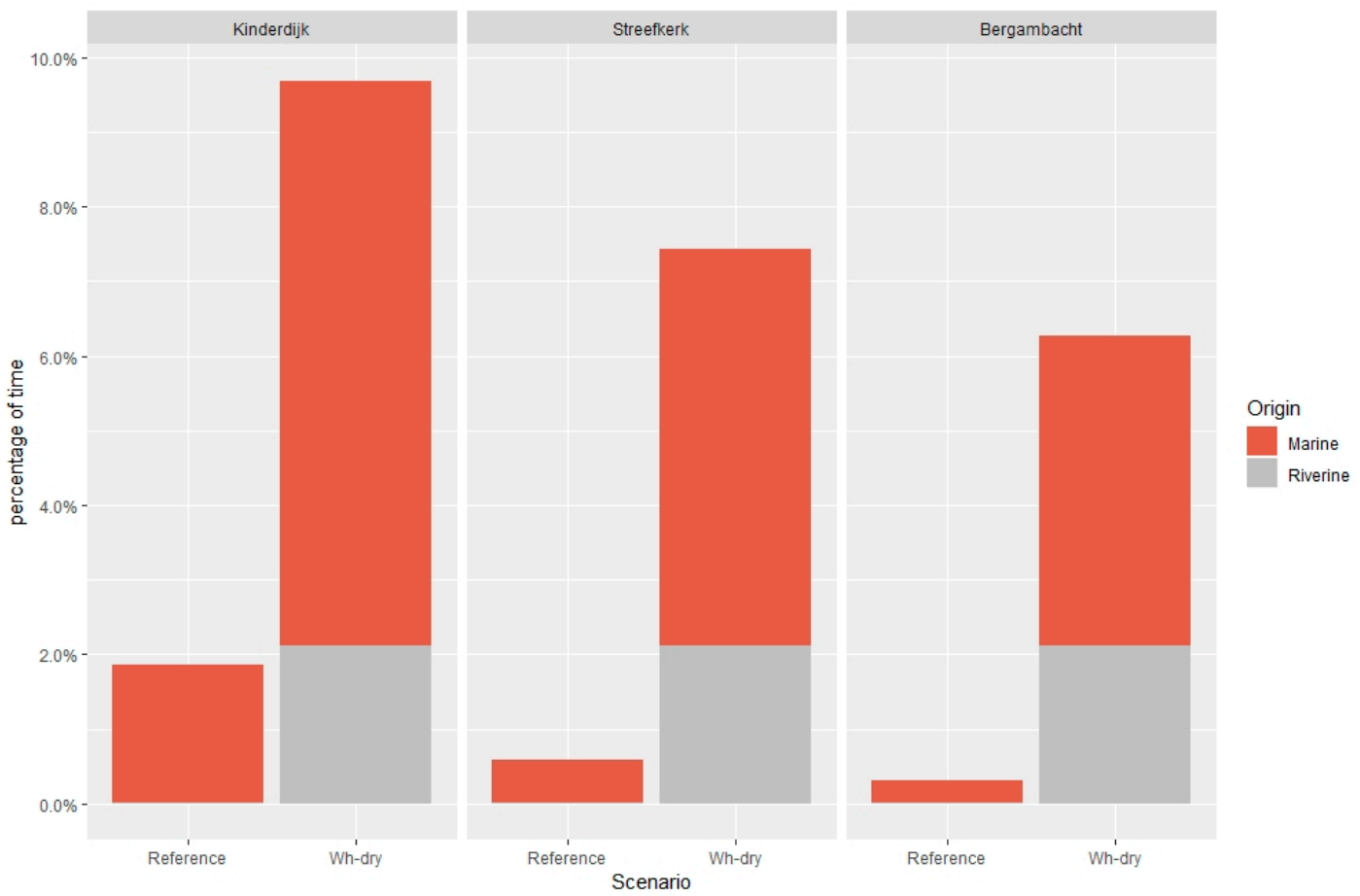

Figure 7. Exceedance of the maximum allowable chloride concentration at the three drinking water inlet locations, based on model calculations 1961-2011, under current conditions (Reference) and Wh-dry conditions. The threshold level is $150 \mathrm{mg} / \mathrm{L}$. Exceedance of the threshold level can be due to a high riverine concentration in the river water $(>150 \mathrm{mg} / \mathrm{L}$ ) or to enhanced seawater intrusion (marine).

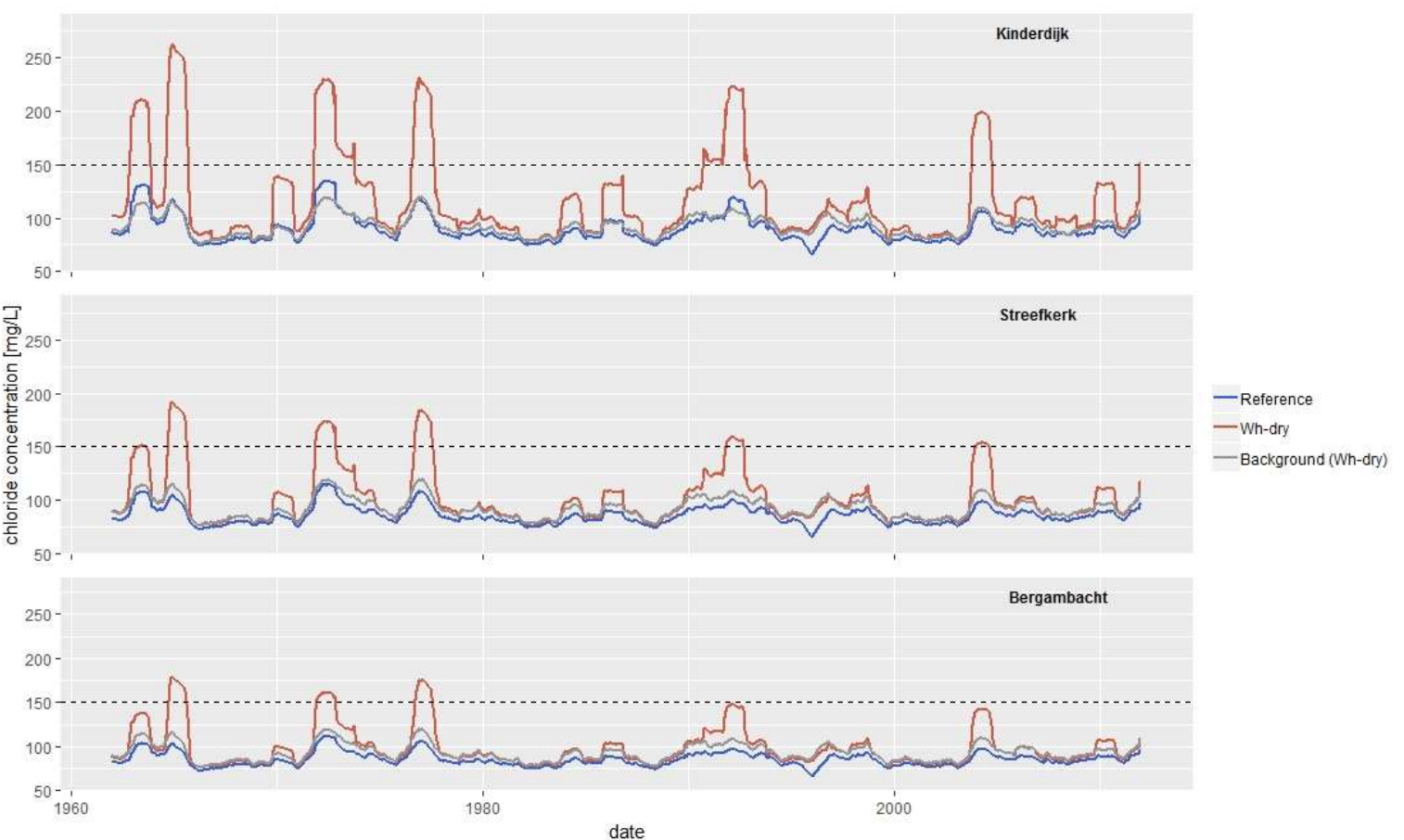

Figure 8. The 365-day moving average chloride concentration at the three drinking water inlet locations (based on calculations 1961-2011). The threshold level is $150 \mathrm{mg} / \mathrm{L}$, averaged over the year, as a moving average.

At Bergambacht, the direct intake of river water is suspended when the chloride concentration exceeds the threshold level of $150 \mathrm{mg} / \mathrm{L}$. This period of suspension can be continued for approx. 20 consecutive days without causing disturbances in the drinking water supply, due to the presence of 
a freshwater buffer in the coastal dunes. During the 50-year analysis period, in the current climate, only one exceedance with a duration of 20 days or more was identified. In the Wh-dry scenario, this number rises to 17. Table 3 shows the ten longest periods of exceedance. Please note that all salinization events occur in the second half of the year, most of them in the fourth quarter. This is due to the seasonal dynamics of the Rhine river with a minimum flow in the fourth quarter, and to the start of the storm season in the month September, leading to elevated seawater levels at the coast.

Table 3. The 10 longest periods of exceedance of the chloride threshold concentration $(150 \mathrm{mg} / \mathrm{L})$ at Bergambacht (direct intake of river water) in the reference situation (current climate) and the future climate Wh-dry scenario. Sorted on highest to lowest durations under Wh-dry conditions.

\begin{tabular}{ccccc}
\hline Nr. & Year & $\begin{array}{c}\text { Duration } \\
\text { (days) } \\
\text { Ref }\end{array}$ & $\begin{array}{c}\text { Duration } \\
\text { (days) } \\
\text { Wh-dry }\end{array}$ & Time of Year \\
\hline 1 & 1976 & - & 152 & Jul-Dec \\
\hline 2 & 1964 & - & 116 & Jul-Nov \\
\hline 3 & 2003 & 1 & 110 & Aug-Dec \\
\hline 4 & 1971 & 27 & 97 & Sep-Dec \\
\hline 5 & 1962 & 10 & 77 & Okt-Dec \\
\hline 6 & 1991 & 1 & 69 & Sep-Nov \\
\hline 7 & 1990 & - & 65 & Sep-Nov \\
\hline 8 & 2009 & - & 54 & Sep-Nov \\
\hline 9 & 1972 & 7 & 43 & Oct-Nov \\
\hline 10 & 1985 & - & 41 & Oct-Nov \\
\hline
\end{tabular}

\subsection{Mitigation of Salinization through Adjusted River Water Allocation}

The eventual aim of this study is to assess the effects of passing a minimum flow of water through the upstream Hagestein weir (see Figure 2) on the salinization of the drinking water inlets along the Lek. Two variants of this strategy are analyzed in this section: maintaining a minimum discharge of $20 \mathrm{~m}^{3} / \mathrm{s}$ and $40 \mathrm{~m}^{3} / \mathrm{s}$, respectively, at Hagestein. This extra water is extracted from the Waal branch, in order to respect the water balance. All other boundary conditions and model settings are unchanged compared to the Wh-dry scenario presented earlier, except for the dispersion coefficient, as described in the method section. The analysis follows the same steps as the previous section.

Analogous to Figure 7, Figure 9 shows the effects of maintaining a minimum discharge of 20 and $40 \mathrm{~m}^{3} / \mathrm{s}$ on the Lek river on the number of days in which the chloride threshold of $150 \mathrm{mg} / \mathrm{L}$ is exceeded in the Wh-dry scenario (in the 50-year period considered).

The results summarized in Figure 9 show that maintaining a minimum upstream discharge of $20 \mathrm{~m}^{3} / \mathrm{s}$ reduces the exceedance time about 1 to 2 percent at the locations Bergambacht and Streefkerk (a 20-25 percent decrease). A minimum discharge of $40 \mathrm{~m}^{3} / \mathrm{s}$ decreases this percentage by 30-35 percent. At Kinderdijk, the calculated effect is very small. This is explained by the fact that Kinderdijk is within the normal tidal range of the Lek. An upstream discharge up to $40 \mathrm{~m}^{3} / \mathrm{s}$ is very small compared with the volumes of water exchanged during a tidal cycle. Further upstream, the dominance of this alternating advective salt transport diminishes, and the upstream-directed dispersive flux becomes increasingly important for the net longitudinal salt transport. A sufficient increase in the upstream discharge may counterbalance this dispersive salt transport. 

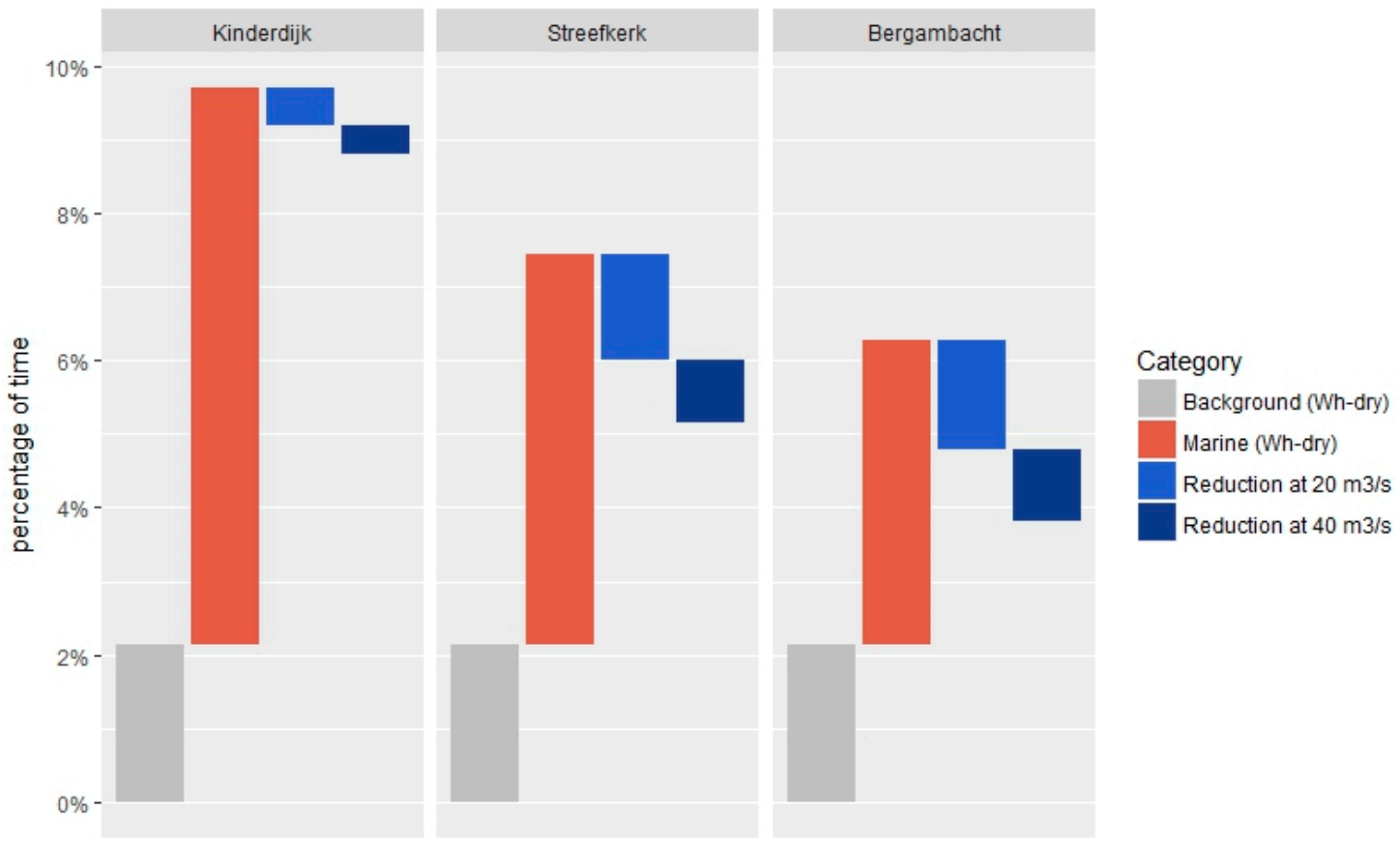

Figure 9. Percentage of time of exceedance of the threshold chloride concentration in the Wh-dry scenario (grey bar plus brown bar) and reduction of this percentage due to maintaining a minimum Lek discharge of 20 and $40 \mathrm{~m}^{3} / \mathrm{s}$ (light blue and dark blue bars, respectively).

Figure 10 shows that the annual average chloride concentration at Streefkerk can be kept below the maximum allowable level of $150 \mathrm{mg} / \mathrm{L}$ by maintaining a minimum upstream discharge of $40 \mathrm{~m}^{3} / \mathrm{s}$. A minimum discharge of $20 \mathrm{~m}^{3} / \mathrm{s}$ also causes a major decrease, but still results in three periods of limited exceedance in the 50 year period.

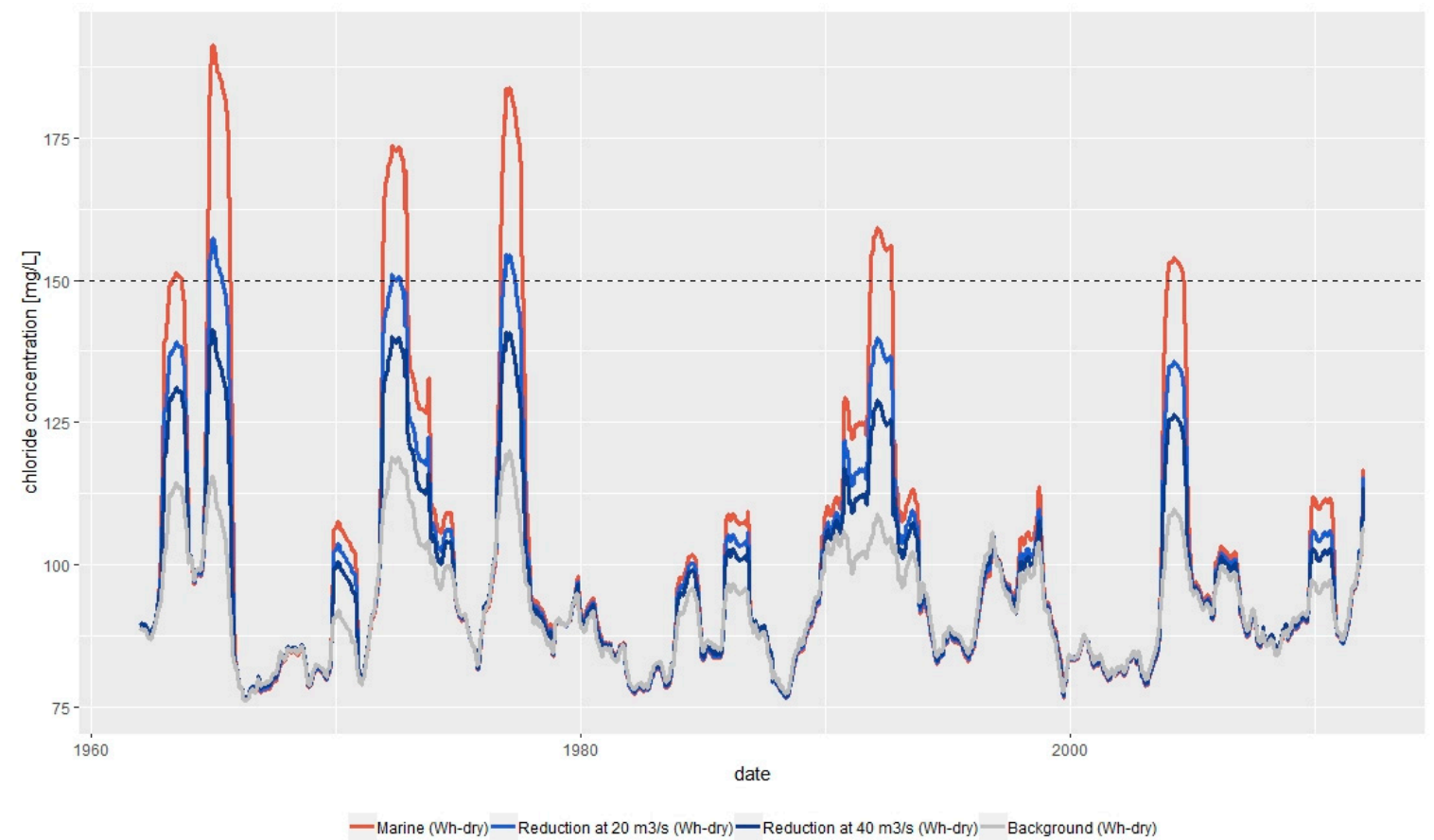

Figure 10. Effect of maintaining a minimum upstream discharge of 20 and $40 \mathrm{~m}^{3} / \mathrm{s}$ on the 365-day moving average chloride concentration at Streefkerk 1961-2011. 
For the direct inlet at Bergambacht, maintaining a minimum upstream discharge affects both the duration of an exceedance and the maximum chloride concentration. Furthermore, long events can be split into two or more shorter events, as the chloride concentration temporarily drops below the maximum allowable level during a Wh-dry event. Due to this effect, the number of events with a duration of 20 days or more decreases from 17 (with a total length of 1006 days) to 15 (719 days) in the $20 \mathrm{~m}^{3} / \mathrm{s}$ variant and 12 (512 days) in the $40 \mathrm{~m}^{3} / \mathrm{s}$ variant.

\section{Discussion and Conclusions}

Below, the results are discussed in view of the uncertainties of the 1D modelling approach and conclusions are drawn. Firstly, the effect of climate change on the salinity intrusion of the Lek and the impact on the drinking water inlets is discussed. Thereafter the effectiveness of the measure is evaluated, including a notion on strategic choices in water distribution to serve different purposes.

Calculations of a 50 year time series show that in the current climate, the instant exceedance of the limit of $150 \mathrm{mg} \mathrm{Cl} / \mathrm{L}$ is limited (less than $2 \%$ for all locations), the 365-day moving average is at least about $15 \mathrm{mg} \mathrm{Cl} / \mathrm{L}$ away from exceeding the $150 \mathrm{mg} \mathrm{Cl} / \mathrm{L}$ and that there is only one event of 20 consecutive days of exceedance of $150 \mathrm{mg} \mathrm{Cl} / \mathrm{L}$ for the direct inlet at Bergambacht. In the Wh-dry scenario, these numbers show a significant increase. Instant exceedances of the $150 \mathrm{mg} \mathrm{Cl} / \mathrm{L}$ norm increase from less than a few percent of the time to $\sim 6-10 \%$, the 365-day moving average exceeds the $150 \mathrm{mg} \mathrm{Cl} / \mathrm{L}$ threshold for several times and at the direct inlet at Bergambacht over 10 periods of long-term exceedance of the limit are calculated. Though the validation showed that exact exceedance numbers and duration of the threshold of $150 \mathrm{mg} \mathrm{Cl} / \mathrm{L}$ cannot be obtained from the 1D model, a global indication can be retrieved. It can therefore be concluded that in a current climate, the water inlets rarely face problems and that this will change in future climate. As there are indications that the chosen 1D approach may lead to a relatively low response to mean sea level rise [24], the influence of climate change on the salt intrusion and related exceedance times may even be stronger.

Another important finding is that salinization on the Lek is not solely related to the connection to the sea. The chloride load on the Rhine has been strongly reduced since the 1960s [19], such that in current climate, even during low discharge events, when the chloride load is less diluted, the maximum allowable concentration for drinking water is hardly ever exceeded (Figure 4). In the Wh-dry scenario, the chloride concentration of the Rhine increases considerably during low river flows, accounting for about $2 \%$ of the exceedance. In contrast to the influence of chloride of marine origin, which mostly affects the downstream locations, riverine chloride affects all stations equally. It should be noted that the relationship between discharge and chloride concentration at the German-Dutch border used in this study [13] is based on measurements from 2011. As between 1997-2008 a rapid decrease was observed in the chloride load on the Rhine [9] it is relevant to know whether further changes have occurred in recent years.

Calculations show that maintaining a minimum upstream discharge of several tens of cubic meters per second reduce the risk of salinization at the inlet locations. However, the increased influence of seawater intrusion on the drinking water inlets cannot be fully compensated for by this measure. The increased upstream discharge is most effective in counteracting the inward salt transport by mixing processes that cause longitudinal dispersion, but less effective in counteracting the salt transport caused by tides and storm surges, as the extra discharge is small compared to the large volumes of water exchanged during these events. Consequently, the effect at Kinderdijk is limited while further upstream at Streefkerk and Bergambacht, several tens of cubic meters per second on the Lek reduce the salinity intrusion events to the level that will cause limited hindrance to the fresh water intake in the Wh-dry scenario.

This study aims at assessing the risk of exposure of the drinking water inlet locations to salinization and of the reduction that can be achieved by reallocating the available water over de Rhine branches. It can be concluded that diverting water onto the Lek is an effective measure to reduce the risk of salinization at Bergambacht and Streefkerk. Kinderdijk is well within the tidal excursion of the Lek 
and cannot profit from a relatively small upstream surplus. For individual events however, the operational question of how much water should be passed through the weir at Hagestein cannot be answered by the results presented here. This requires more precise estimates, which are expected to be obtained by carrying out a hybrid $1 \mathrm{D}$ and 3D approach. Given the more detailed representation of the physical processes within a 3D model, time slices of the $1 \mathrm{D}$ result could be selected and recalculated. By this means, estimates for the effect of climate change on the salinity intrusion during particular low river-discharge events and the required discharge surplus can be improved.

The extra water discharged onto the Lek comes at a cost. It cannot be used elsewhere in the river and adjacent channel system to sustain fresh water demands for water quality (flushing), irrigation and navigability. Also, the extra water is extracted from the Waal river, which is the main inland shipping channel for the port of Rotterdam. During low discharges of the Rhine, water levels on the Waal are very critical, as they determine the allowed depths of ships and hence the loads they can carry. The potential gain of the extra water for the drinking water inlets along the Lek has to be balanced against the impact of this measure on water level and stream flows in other parts and functions of the delta system. This calls for more precise estimates of both the climate effect and the amount of discharge needed for particular events to counteract the salinity intrusion.

Author Contributions: Conceptualization, M.B. and G.Z.; Methodology, M.V., Y.H. and M.B.; Supervision, M.B.; Validation, Y.H.; Visualization, M.V. and G.Z.; Writing-original draft, M.V. and Y.H.; Writing一review \& editing, M.B. and G.Z.

Funding: This study was funded by the National Association of Water Companies in The Netherlands (VEWIN) and the water companies Oasen and Dunea.

Acknowledgments: The authors would like to thank A. Kersbergen at HydroLogic for her diligent work in processing large amounts of data into useful insights. Also, we would like to thank M. Mens at Deltares and $\mathrm{N}$. Kielen at Rijkswaterstaat for their valuable comments during the preparation of this article. We further thank C. Kuyper for his valuable input on the system dynamics of salinity intrusion on the Lek.

Conflicts of Interest: One of the co-authors (Gertjan Zwolsman) is employed at water company Dunea, which financed $25 \%$ of this study. He contributed to the design of the study and the visualization of the results, but was not involved in the data collection and modelling part of the study. In addition, he reviewed the MS on style and consistency, but had no influence on the interpretation of the model results.

\section{References}

1. Lenderink, G.; Beersma, J. The KNMI'14 WH, Dry Scenario for the Rhine and Meuse Basins; KNMI: De Bilt, The Netherlands, 2015.

2. Sperna Weiland, F.; Hegnauer, M.; Bouaziz, L.; Beersma, J. Implications of the KNMI'14 Climate Scenarios for the Discharge of the Rhine and Meuse, Comparison with Earlier Scenario Studies; Deltares: Delft, The Netherlands, 2015.

3. Klijn, F.; Ter Maat, J.; Van Velzen, E. Zoetwatervoorziening in Nederland, Landelijke Analyse Knelpunten in de 21e Eeuw; Deltares: Delft, The Netherlands, 2011. (In Dutch)

4. Mens, M.; Van der Wijk, R.; Kramer, N.; Hunink, J.; de Jong, B.J.; Becker, P.; Gijsbers, P.; Ten Velden, C. Hotspotanalyses voor Het Deltaprogramma Zoetwater: Inhoudelijke Rapportage; Deltares: Delft, The Netherlands, 2018; p. 149. (In Dutch)

5. Van Waterstaat, M.I. En Delta Programme-Government.nl. Available online: https://www.government.nl/ topics/delta-programme (accessed on 19 February 2019).

6. Van der Kooij, D. Drinkwater uit Oevergrondwater: Hydrologie, Kwaliteit en Zuivering; Mededeling; Keuringsinstituut voor Waterleidingartikelen: Nieuwegein, The Netherlands, 1985. (In Dutch)

7. Kuijper, C. Analyse van Zoutmetingen in de Lek, Met Schatting Dispersiecoefficient; Deltares: Delft, The Netherlands, 2017; p. 76. (In Dutch)

8. Savenije, H.H.G. Salinity and Tides in Alluvial Estuaries, 2nd completely revised ed.; version 2.5; Delft University of Technology: Delft, The Netherlands, 2012.

9. Bonte, M.; Zwolsman, G. Klimaatverandering en verzoeting van de Rijn. H2O 2009, 3, 29-31. (In Dutch)

10. Cunge, J.A.; Holly, F.M.; Verwey, A. Practical Aspects of Computational River Hydraulics; Pitman: Boston, MA, USA; London, UK; Melbourne, Australia, 1980; ISBN 978-0-273-08442-6. 
11. Rijkswaterstaat National Water Model. Available online: https://www.helpdeskwater.nl/onderwerpen/ applicaties-modellen/applicaties-per/watermanagement/watermanagement/nationaal-water / technische/zoetwaterverdeling/ (accessed on 7 November 2018).

12. Prinsen, G.; Sperna Weiland, F.; Ruijgh, E. The Delta Model for Fresh Water Policy Analysis in The Netherlands. Water Resour. Manag. 2015, 29, 645-661. [CrossRef]

13. Hunink, J.; Hegnauer, M. Update Deltascenario's Nationaal Water Model; Deltares: Delft, The Netherlands, 2015. (In Dutch)

14. Hunink, J.; Delsman, J.; Prinsen, G.; Bos-Burgering, L.; Mulder, N.; Visser, M. Vertaling van Deltascenario's 2017 Naar Modelinvoer voor Het Nationaal Water Model; Deltares: Delft, The Netherlands, 2018. (In Dutch)

15. Deltares Nationaal Water Model—Nationaal Water Model—Deltares Public Wiki. Available online: https: / / publicwiki.deltares.nl/display/NW/ (accessed on 27 February 2019).

16. Salt Intrusion, Technical Reference; Sobek-RE Documentation; Deltares: Delft, The Netherlands, 2012.

17. Thatcher, M.; Harleman, D. A mathematical model for the prediction of unsteady salinity intrusion in estuaries. In R.M. Parsons Laboratory Report; MIT: Cambridge, MA, USA, 1972.

18. Rijkswaterstaat. IJking Chloridedeel ZWENDL Noordelijk Deltabekken (Stand van Zaken September 1984); Rijkswaterstaat: Rotterdam, The Netherlands, 1984. (In Dutch)

19. Huismans, Y.; Buschman, F.; Wesselius, C.; Daniels, J.; Kuijper, C. Modelleren van Zoutverspreiding Met SOBEK 3 en SOBEK-RE; Deltares: Delft, The Netherlands, 2016. (In Dutch)

20. Kraaijeveld, M. Een SOBEK-Model van Het Noordelijk Deltabekken; Kalibratie en Verificatie Zoutbeweging Noordrand; Rijkswaterstaat: Dordrecht, The Netherlands, 2003. (In Dutch)

21. Jansen, M.H.P.; Collard, E.A. Herkalibratie van de Zoutverdeling NDB-Model Fase 2; Svasek Hydraulics: Rotterdam, The Netherlands, 2005. (In Dutch)

22. Huismans, Y.; van der Wijk, R.; Fujisaki, A.; Sloff, C.J. Zoutindringing in de Rijn-Maasmonding: Knelpunten en Effectiviteit Stuurknoppen; Deltares: Delft, The Netherlands, 2018. (In Dutch)

23. KNMI. KNMI Climate Scenarios. Available online: http:/ / www.climatescenarios.nl/scenarios_summary/ index.html (accessed on 7 November 2018).

24. Daniels, J. Dispersion and Dynamically One-Dimensional Modeling of Salt Transport in Estuaries. Master's Thesis, Delft University of Technology, Delft, The Netherlands, National University of Singapore, Singapore, 2016.

(C) 2019 by the authors. Licensee MDPI, Basel, Switzerland. This article is an open access article distributed under the terms and conditions of the Creative Commons Attribution (CC BY) license (http://creativecommons.org/licenses/by/4.0/). 